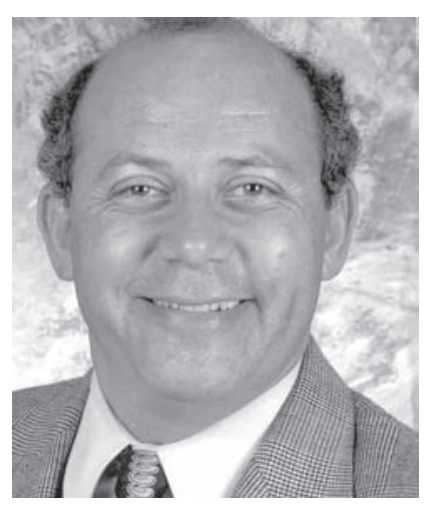

\title{
The Research Connection
}

\section{Recent Research in Young Adult Literature:}

Three Predominant Strands of Study

$\mathbf{F}$ or this research column, three recent journal articles caught my attention. They represent, in my estimation, three predominant strands in the study of young adult literature. The first strand is the preponderance of the use of young adult literature to inspire, and perhaps, change the lives of young people. Often, teachers, parents, social workers and youth leaders will use young adult literature to hold up a mirror to young adults to see something that they might not ordinarily recognize in themselves. In Sue Jacobs's article on the reaction of imprisoned youth to the reading and discussing of young adult literature, we see just that.

The second strand of study is the power of young adult literature to reveal the hidden and often confusing lives of young adults, particularly in today's world for those whose sexual orientation differs from the acceptable norm. In Emily Meixner's good work on the lives of young adult children who are lesbian, gay, bisexual, transgender and/or queer, we get a first-hand glimpse of what it means to read (or maybe, not read) about yourself when your self-identity is not considered the norm.

And the third strand is the changing face of young adult literature and how its reflective nature mirrors societal norms and expectations. Diane Emge's article on how young adult novels reflect the societal expectations of young girls who find themselves pregnant and the resultant choices they make provides a vivid example of how literature mirrors life, and sometimes, the reverse.

All three articles are a startling glimpse at the revealing and evolving face of young adult literature and add considerably to our understanding of ourselves and the role of young adult literature to reflect the changing perceptions of our world.

\section{Incarcerated Youth and Young Adult-Literature}

In “Listening, Writing, Drawing: The Artistic Response of Incarcerated Youth to Young-Adult Literature,' (Educational Horizons 84 No2 112-20 Winter 2006), researcher Sue Jacobs garners data obtained from incarcerated male youths to examine these youths' artistic responses to, and interpretations of, young adult literature. Using young adult participants aged between 13 and 17 years of age, Jacobs's research results reveal that the incarcerated male youth's artistic responses, coupled with interviews, provide a forum for youths to understand young adult literature while enjoying an aesthetic activity. Jacobs' research is significant in that it brings depth and context to an often overlooked and under-researched area of young adult literature, the reaction of troubled and even incarcerated youth to a body of literature that is often most relevant to their immediate circumstances and needs.

As Jacobs states, often adolescent males are academically and emotionally detached from the classroom setting (Brozo, 2002). Jacobs writes that early reading and learning failures are precursors to unemployment, crime, drug addiction, homelessness, and prison sentences. Also, as she evidences, boys are three to five 
times more likely than girls to undergo learning or reading disabilities placement in schools (National Center for Educational Statistics, 2000), 50 percent more likely to be retained a grade than girls (Kleinfield, 1999) and of the estimated 500,000 to 1 million students who annually drop out of high schools in the United States, more than 55 percent are boys (National Center for Education Statistics 1998).

Jacobs believes that one remedy for these depressing numbers is to help adolescent boys become more engaged in reading and listening. Developing readers at a young age, she asserts, helps them become lifelong learners (Young and Brozo 2001). Moreover, she proposes that if young males are to be engaged in their reading, then the objective of traditional reading instruction must be dramatically changed.

In many traditional middlelevel language arts classrooms, students must respond to assigned literature either orally, or more typically, in writing. Students are asked to explain or discuss their answers to the selected reading. The teacher decides whether the students are answering the questions "correctly"-usually how the teacher believes they should be answered. Such traditional approaches often slight the affective area of literature by regarding meaning as residing in the text.

In contrast, as Jacobs writes, Rosenblatt indicates in 1978 that an aesthetic response to literature can help the reader participate in a lived-through experience, thus creating a higher level of engagement and interaction. Thus, the reader is more likely to become engaged if the affective areas of engagement and checking for understanding are addressed. Nonetheless, acquiring technical knowledge, rather than concentrating on the initial affective aesthetic response and finding enjoyment in the literature, has too often been traditional instruction's major concern (Chasser 1977).

Armed with this belief, Jacobs undertook a study to examine the types of artistic responses and personal interpretations that incarcerated male youths make as they listened and responded to selected pieces of young-adult literature. Often, because of the extreme situations such youths

\section{Jacobs writes that early} reading and learning failures are precursors to unemployment, crime, drug addiction, homelessness, and prison sentences. Also, as she evidences, boys are three to five more times more likely than girls to undergo learning or reading disabilities placement in schools (National Center for Educational Statistics, 2000). have experienced-abuse, school difficulties, and frequent involvement with the criminal justice system-they operate at an intense emotional level that may endanger themselves and others. Thus, Jacobs believes that their prior experiences would add a unique perspective to their story interpretations.

Jacobs' study utilizes qualitative and quantitative methodology to gather information about incarcerated youth and their responses to young adult literature. The information gathered is reported as individual case studies. The population under study is incarcerated male youths ranging in age from thirteen to seventeen.

Many have lengthy criminal histories of absconding from home or placements, school truancy, and deviant behavior such as assault, theft, and the use of drugs and alcohol.

These youths chose novels from a list provided; the researcher conducted a "book talk" on each; and the youths then voted on the top three they wanted read to them. The favorites were Moon over Tennessee (Crist-Evans, 1999), Tenderness (Cormier, 1997), and Surviving the Applewhites (Tolan, 2002).

During each session the researcher read for forty-five minutes, and afterward the youths responded using a choice of art medium. Then each youth, interviewed individually, responded to oral prompts about his art piece. Each one explained his picture, how it related to his personal life, and whether it brought forth any memories of people, places, or situations. 
To determine attitudes toward reading, the youths were given preand post-tests modified from the Denver Reading Attitude Survey (Rhodes, 1992). They were also given an Interest Inventory (Hill and Ruptic, 1994), modified to help establish common ground between the individuals and the researcher. The interviews with the incarcerated male youths were transcribed and included in the text.

Using Squire's Classification Methods for Response to Literature (Squire, 1964), each drawing was documented under literary judgments, interpretational responses, narrational responses, associational responses, self-involvement, prescriptive judgments, and miscellaneous. The responses were examined in their entirety. An analysis of the data reveals thirtyseven responses placed in Squire's Framework (1964). None fell into the literary-judgment category, thirteen into interpretational, and eight into narrational response. Of the remaining, six responses deal with associational responses, eight with self-involvement, and one each with prescriptive judgments and miscellaneous.

Initially, the youths seemed to rely on safe responses, but as they were encouraged, they began to take risks with their artistic responses. They started to make judgments and applications, such as living in foster homes, dealing with drugs, and gang violence, to their lives.

The results of this study indicate that artistic responses are another vehicle incarcerated male youth may use when responding to young adult literature. The findings did show that artistic responses

\section{The results of this study indicate that artistic re- \\ sponses are another \\ vehicle incarcerated male}

youth may use when

responding to young adult

literature. The findings did

show that artistic re-

sponses coupled with

interviews provide a fo-

rum for youths to under-

stand young adult litera-

ture while they enjoyed

an aesthetic activity.

coupled with interviews provide a forum for youths to understand young adult literature while they enjoy an aesthetic activity. The youths also learn about themselves, including concerns and attitudes surrounding their situations. Jacobs concludes that educators can accomplish that by understanding the response process, which can incorporate literature that reflects the world around us.

\section{Sexual Orientation and Young Adult Literature}

In "Teacher Agency and Access to LGBTQ Young Adult Literature,” (Radical Teacher, 76, (2006): 13-19), researcher and teacher educator Emily Meixner conducted an action research project with undergraduate students at the College of New Jersey to introduce student teachers to lesbian, gay, bisexual, transgender and queer young adult literature and to motivate them to conduct their own action research projects on the availability of such literature in school and local library collections.

Meixner is drawn to a study of young adult literature about issues of sexual orientation for three reasons. First, she was curious about the power of stories to elicit empathy. She wants to know if stories about homosexual and transgender behavior could provide students with an opportunity to experience (albeit vicariously) what their future Lesbian, Gay, Bisexual, Transgender Queer (LGBTQ) middle and high school students might be going through-their feelings, their struggles and successes, and the experiences through which they were and were not marginalized.

The second reason is curricular. Not only did Meixner want her students to become aware of their LGBTQ students' experiences, she also wants them to be able to share, recommend, and read these texts in their classrooms. The more familiar they are with these texts, she believes, the more likely they would be to use them in their secondary English classes and the more they do, the more opportunities they will have to combat heterosexism and homophobia and stem the tide of violence currently perpetrated on LGBTQ students in schools.

Finally, the third reason is the ever-present need for students to think beyond specific school or classroom instances of violence and examine the effects of the heterosexism and homophobia 


\section{Students also need to} read their own life stories, casting a critical eye on their own ideologies and how their lives in schools, churches, and families, as well as their encounters with the media and other public and private institutions, shaped who they are and what they hoped to accomplish as teachers.

present in our own lives and the institutions with which we are associated. In addition to studying the experiences of the adolescents in the literature they are reading, Meixner insists, students also need to read their own life stories, casting a critical eye on their own ideologies and how their lives in schools, churches, and families, as well as their encounters with the media and other public and private institutions, shaped who they are and what they hoped to accomplish as teachers.

Meixner's reasons for her study about her students' access to LGBTQ young adult literature manifest itself into surprising forms. First, she provides the opportunity for her students to open up about their own feelings about sexual orientation behavior and express their reaction to young adult literature that dealt with such themes. And second, her students-independent of Meixnermet, discussed, and designed an action research project in which they would investigate adolescents' access to books such as those they had been reading in class.

Together, Meixner's education students created an interview protocol for investigating the use of gender-related books in school and local public libraries. Then, each of the students decided they would visit and conduct interviews with librarians at four libraries including two county/public libraries, one high school library, and one middle school library.

In the protocol, they requested information about the number of volumes in the libraries' adolescent collections, as well as the percentage or number of those texts that dealt specifically with issues pertaining to adolescent gender and sexuality. They also asked a series of questions about the process through which books were added to the collection, challenges to books currently available at the library, the librarians' familiarity with books on, by, or about LGBTQ youth, academic and public requests for these books, and the availability of (library-based) outreach programs specifically targeted toward LGBTQ adolescents. Once all of the interviews had been completed, they compiled and analyzed their findings.

As the students conduct their interviews, they are met with both enthusiasm and resistance from the librarians with whom they spoke. Although several librarians respond suspiciously to the students' inquiries, most are helpful and genuinely excited to have an opportunity to talk about their collections. Fourteen of the twenty librarians state that they are familiar with at least several LGBTQ young adult titles. And, even if they did not have wide-ranging knowledge of the genre or the subject matter, they (along with the other six librarians who had not read any LGBTQ young adult literature) feel confident that they can make informed recommendations when and if they were asked.

What the students discover, however, is that rarely had the librarians been asked. Very few could recall being approached by students, parents, or other patrons looking for young adult books about adolescent sexuality or with gay and lesbian characters or themes. Librarians at the public libraries cite very few inquiries from teachers. The situation at school libraries differs only slightly. There, librarians feel that their collections enhanced classroom instruction, but they acknowledge that they rarely receive requests from teachers for book talks on or texts about LGBTQ adolescents or adolescent sexuality. In most cases, they asserted, students were simply not researching these topics in class. Only in one high school library-a school with a very active Gay-Straight Alliance-did a librarian recollect teachers regularly seeking out books on adolescent gender and sexuality.

And, to her students' surprise, most of the LGBTQ literature they encounter in school collections are non-fiction rather than fiction.

Rarely did any of the libraries provide LGBTQ outreach. None of the public libraries provide book 
talks, discussion groups, speakers, or programmatic opportunities specifically targeted toward LBGTQ adolescents and their families. (Of course, "one would be held if people showed enough interest," said one librarian.) At the middle schools, outreach is not quite so infrequent because of their affiliations with high schools. For example, many of the middle school librarians cite support such as a gay-straight read-in, a student/ community forum on LGBTQ concerns, and the existence of GayStraight Alliances and Parents, Family and Friends of Lesbians and Gays (PFLAG) at their associated high schools. Of the high school librarians to whom the students spoke, only one of the five express serious reservations about providing LGBTQ outreach through the library. Outreach is the responsibility of guidance, Meixner states, and LGBTQ support organizations "would lead to ridicule and controversy in the district.” In contrast, the other four librarians were much more open to and familiar with the aforementioned outreach opportunities.

Thus, while Meixner believes the course did provide her students with an experience that will make them better advocates for their LGBTQ students, and while she contends that engaging in this action research project is crucial to their developing social consciousness and political agency, how both of these events ultimately affect their teaching remains to be seen. As her students graduate and begin teaching, Meixner hopes that her students will remember and hold onto their experiences-that they will continue to challenge inequi- table institutions - and that increased institutional awareness will inform the way in which they work to counteract violence and height for truly safe schools.

\section{Sex, Pregnancy, and Young Adult Literature}

In Diane Emge's “I'm Pregnant!: Fear and Conception in Four Decades of Young Adult Literature," Young Adult Library Services (2006, Vol. 4, issue 2, pp. 22-27), the author, a librarian, discusses the predominant themes of the portrayal of teenage sexual behavior and consequences in four decades of American young adult fiction

\section{Thus, while Meixner be-}

lieves the course did provide her students with an experience that will make them better advocates for their LGBTQ students, and while she contends that engaging in this action research project is crucial to their developing social consciousness and political agency, how both of these events ultimately affect their teaching remains to

be seen.
(1960-1990). Specifically, the author focuses on the topics of birth control, teenage pregnancy, teenage marriage, abortion, single mothers, and single fathers. As the author argues, these fictitious depictions of adolescent experiences have a powerful effect on teenage readers. For many, the strong sense of identification with fictitious characters involved in similar experiences and circumstances provides young adults with a ready and easy companion in times of great uncertainty and turmoil. The author also argues that changes in American society regarding teenage sexuality and behavior since the 1960s have been partially, if not directly, a result of its explicit and reflective depiction in the four decades publication of young adult fiction.

"In 1968," the author writes, "most teenage girls understood birth control to mean keeping their legs crossed” (22). "Good girls," as the euphemism was called, did not have sexual urges, and their primary challenge was to keep "bad boys" away from them. Naturally, as the author remarks, only "bad girls" in this era of quiet conformity allowed their passion to overcome their common sense and permit young men to violate their privates.

In the 1960s and '70s, teenage pregnancy was very upsetting to gentle society. In the seminal young adult novel, Mr. and Mrs. Bo Jo Jones, two young adults are shown wreathing in agony at even the thought of the girl becoming pregnant. July, the teenage girl in the 'throes of a heated affair' with another teenager, Bo, writhes in complete agony until her next period arrives. In this early and 
groundbreaking work, July does try to get birth control pills, but to no avail. Through a complicated process involving a buying a fake wedding ring and taking a bus fifty miles to another town, July seeks in vain as the doctor she visits sends her home with no pills and an admonition to speak to her parents.

Speaking to her parents, though, turns out to be the least of her problems. Soon, July learns that she is pregnant, and after breaking the news to her boyfriend, Bo, they decide together to do the only imaginable thing possible in "the then world of young adult novels,"-three days later, they decide to get married.

Since 1968 and the premier of Mr. and Mrs. Bo Jo Jones, times and circumstances have changed considerably. For one thing, as the author concedes, birth control measures are readily available to young people. Condoms are readily available at nearly every store possible, and birth control pills no longer require a secretive mission to obtain. Medical doctors are trained to ask young girls about their own sexual behavior and readily recommend precautions. Laws governing abortion, contraception and adoption have changed and today, it is more acceptable to become a single parent.

Knowing this, the question the author poses is "does teenage pregnancy still ruin lives?” (22). The author believes that by examining the mirror world of young adult literature, we can derive a sense of the teen pregnancy experience. "Despite the fact it is a step removed from actual experience," Emge writes, "the fictitious experiences portrayed in novels are powerful influences on teen readers" (22). This is particularly true in the delicate issue of teen pregnancy, Emge believes, because much of the agonizing and decision-making occurs before the girl has revealed her condition to anyone else. Often, the author writes, the fictitious characters in novels may be the only understanding companion they have in the earliest and crucial days of their pregnancy.

With this in mind, the author examines the various aspects of teen pregnancy as it has been depicted in the novels of the past forty years (1960-2000) and determines if differences in societal norms have made teen pregnancy a different experiences than it was for the young teenager, July, in $M r$. and Mrs. Bo Jo Jones.

What the researcher finds is that although the talk of teenage sex and its inherent sexual consequences are more open and accepting in today's young adult novels, the pain, hurt, confusion and despair associated with young love, passion, and heartbreak have not changed. In today's novels, teens just have more options to reconcile their emotional and behavioral choices and consequences.

For example, Emge writes, birth control pills have been around a long time, but not for unmarried teenagers and not for unmarried teenagers in young adult novels. In 1973, Winifred Madison's young adult novel Growing Up in a Hurry (New York, Little, Brown), Karen finds her older sister's pills hidden in her room and reacts with horror. "I was so shocked my hand trembled. It never occurred to me that Pam would be using pills, doing that, or that it could upset me so much to find out about it" (40). Whereas in a contemporary novel, such as Jesse McGuire's 1991 young adult novel Over the Edge (New York, Butterfield Press), the lead character, a pregnant young mother-to-be named Caroline muses that she can "almost taste the irony. After all these years of taking precautions, I finally get caught. Funny, it had never occurred to her that she'd end up on the wrong side of the birth rate method safety-rate statistics," (401). Mentioning birth control statistics is not something a teenager would have done in the 1960s and '70s.

Similarly, in early young adult novels, teenage pregnancy would be dutifully followed by teenage marriage. In Ann Head's Mr. and Mrs. Bo Jo Jones (1968), Paul Zindel's My Darling, My Hamburger (1969), Richard Peck's Don't Look and It Won't Hurt (1972), and Paul Kropp's Baby, Baby (1984), marriage is considered the right option by young teens confronted with an unwanted pregnancy. But by 1998 , in Annie's Baby: The Diary of Anonymous, a Pregnant Teenager, fourteen-year-old Annie makes the tentative suggestion of getting married to her boyfriend Danny, only to be cruelly rejected. "I'm sixteen years-old, duh-head. You think I am going to stifle my life for you and your slimy bastard?" (110).

As Emge notes, the concept of abortion and its viability to end unwanted teenage pregnancies has only been an option in young adult novels. Even before being nationally legalized in 1972, abortion in young adult novels has been seen 
by teenagers and parents as the method to keep "their secret and shame" hidden and buried forever. In Zindel's My Darling, My Hamburger (1969), young pregnant Liz is at first delighted that her boyfriend has offered to marry her, but she is soon left by him with a quick apology and two hundred dollars to "take care of things." The result is that her badly performed abortion leaves her gravely ill and unable to graduate from high school. The opposite though, occurs in Norma Klein's early and influential work, It's Not What You Expect, where a friend of young Carla, Sara Lee, has an abortion and Carla marvels at how easy it all seems for her. And of course, even though contemporary novels feature teenage girls who opt for an abortion-Calley in Feinberg's Borrowed Light (2000), and Cyd Charrisse in Cohn's Gingerbread, (2002)-and those

\section{As Emge concludes, times}

have changed, but not

emotions. Today, young

people are more edu-

cated-by progressive

parents, teachers, doctors,

celebrities, and the like-

than ever before about

the whys and wherefores

of sexual behavior, but no

less immune to its conse-

quences. who almost, but at the last minute, decide against,-Claudia in Holland's The Search (1991) and Helen in Wild's One Night (2003), the act itself leaves the young protagonists feeling confused, guilty and depressed.

In young adult novels, there was a time when adoption was considered the only viable option. There is young Koral in Evelyn White Minshull's But I Thought You Really Loved Me (1977) and fifteenyear-old Sue Ann in Joanna Lee's I Want to Keep My Baby (1977) where adoption is seen as the only viable option. Even in Ruth Pennebaker's Don't Think Twice (1996), it is 1967 and young pregnant Anne is sent to a home for unwed mothers where she realizes through heartache and despair that life will be better for her newly born child in the hands of loving and supportive parents.

Novels set in a contemporary setting, though, often view adoption as out of the question. Sophie, in Joyce Sweeny's poignant young adult novel Waiting for June (2003), will not even consider giving her baby away, telling her mother emphatically, "Women have to know how to take care of themselves. That's the best thing you ever gave to me. Don't try to take it away from me,” (141). Or take Ben, the agonizing teenage protagonist and young father in Joanne Horniman's Mahalia (2001) who pleads with the biological mother of his child to not take away his daughter after having abandoned her shortly after her birth. "I am sorry that you went through a hard time after she was born. But I was the one who looked after her when you went away and I did a good job of it. I'm good at looking after her. It is the only thing I do really well. I won't let you take her away from me” (177).

As Emge concludes, times have changed, but not emotions. Today, young people are more educatedby progressive parents, teachers, doctors, celebrities, and the likethan ever before about the whys and wherefores of sexual behavior, but no less immune to its consequences. Physically and emotionally, psychologically and intellectually, young people must struggle with the same desires, obsessions and longings that young people have known since time immemorial. Thankfully, we have, as Emge concludes, young adult literature to document our changing times and eternal truths.

\section{Conclusion}

These three studies of young adult literature-though by no means conclusive and/or inclusive of all the issues relevant to today's young adult literature-do underline three predominant strands in the world of young adult fiction. They represent the ability to inspire, challenge, and reflect the social customs and mores of our changing world. Through the eyes of gifted writers and researchers, we learn a little bit about ourselves and much about the potential of young adult fiction to shape and influences the lives of young adults-and ourselves, as well.

Jeffrey Kaplan is Associate Professor of Education at the University of Central Florida Orlando, Florida 32816. Dr. Kaplan can be reached at 407-823-2041 or jkaplan@mail.ucf.edu 


\section{Works Cited}

Brozo, William G. To Be a Boy, To Be a Reader: Engaging Teen and Preteen Boys in Active Literacy. Newark. Del: International Reading Association, 2002.

Chasser, Cheryl C. "How Adolescents' Affective Responses to Four Short Stories Relate to The Factors of Age, Sex and Intelligence." Doctoral Dissertation Abstracts 38.02 (1977): 717A-718A.

Emge, Diane. "I'm Pregnant!: Fear and Conception in Four Decades of Young Adult Literature." Young Adult Library Services 4.2 (2006): 22-27.

Hill, Bonnie C. \&. Ruptic, Cynthia A. Practical Aspects of Authentic Assessment: Putting the Pieces Together. Norwood, Mass.: Christopher Gordon Publishers. 1994.

Jacobs, Sue. "Listening, Writing, Drawing: The Artistic Response of Incarcerated Youth to Young-Adult Literature," Educational Horizons 84.2 (2006): 112-20.

Kleinfield, Judith. "Student Performance: Males versus Females." The Public Interest 134 (Winter, 1999): 3-20.

Meixner, Emily. "Teacher Agency and Access to LGBTQ Young Adult Literature." Radical Teacher 76 (2006): 1319.

National Center for Education Statistics. Trends in Educational Equity of Girls and Women. Washington, DC: U.S.
Department of Education, 2000.

www.nces.ed.gov.

National Center for Education Statistics.

The Condition of Education. Washington, D.C.: U.S. Department of Education, 1998. www.nces.ed.gov.

Young, Josephine P. \& Brozo, William G. "Boys Will Be Boys, or Will They?: Literacy and the Masculinities." Reading Research Quarterly 36 (2001): 316325.

Rhodes, Lynn K. 1991. Literacy Assessment: A Handbook of Instruments. Portsmouth, NH: Heinemann. 1992.

Rosenblatt, Louise. The Reader, The Text, The Poem: The Transactional Theory of the Literary Work. Carbondale, IL: Southern Illinois University Press, 1978.

Squire, James. The Responses of Adolescents While Reading Four Short Stories. Champaign, IL: National Council Teachers of English, 1964.

\section{Young Adult Books}

Anonymous. Annie's Baby: The Diary of Anonymous, a Pregnant Teenager. New York, Avon Books, 1988.

Cohn, Rachel. Gingerbread. New York: Simon and Schuster, 2002.

Cormier, Robert. Tenderness. New York: Delacorte Press, 1977.

Crist-Evans, Craig \& Christensen, Bonnie. Moon over Tennessee: A Boy's Civil War Journal. Boston: Houghton Mifflin Company, 1999.
Head, Ann. Mr. and Mrs. Bo Jo Jones. New York: Signet, 1968.

Feinberg, Anna. Borrowed Light. New York, NY: Delacorte/Random House, 2000.

Holland, Isabelle. The Search. New York: Fawcett, 1991.

Horniman, Joanne. Mahalia. New York: Alfred A. Knopf, 2001.

Klein, Norma. It's Not What You Expect. Pantheon Books, 1973.

Kropp, Paul. Baby, Baby. St. Paul, Minn: EMC, 1984.

Lee, Joanna. I Want to Keep My Baby. New York: Signet, 1977.

Madison, Winifred. Growing Up in a Hurry. Little, Brown \& Co., 1973.

Maguire, Jesse. On the Edge. New York: Butterfield Press, 1991.

Minshull, Evelyn W. But I Thought You Really Loved Me. Westminster/John Knox Press, 1976.

Peck, Richard. Don't Look and It Won't Hurt. New York: Henry Holt, 1972.

Pennebaker, Ruth. Don't Think Twice. New York: Bantam Doubleday Dell, 1996.

Sweeney, June. Waiting for Joyce. New York: Marshall Cavendish, 2003.

Tolan, Stephanie S. Surviving the Applewhites. New York: Harper Collins, 2002.

Wild, Margaret. One Night. New York: Alfred A. Knopf, 2003.

Zach, Cheryl. Runaway. New York: Berkeley, 1995.

Zindel, Paul. My Darling, My Hamburger. New York: Harper \& Row, 1969. 